УДК 349.222

https://doi.org/10.34142/23121661.2020.32.03

orcid.org/0000-0003-2509-865X

( ) Головань Т. Г., 2020

\author{
Т. Г. Головань
}

\title{
ПИТАННЯ ЕФЕКТИВНОСТІ СОЦІАЛЬНОГО ДІАЛОГУ В УКРАЇНІ КРІЗЬ ПРИЗМУ ПРАВОВОГО РЕГУЛЮВАННЯ ЙОГО ПРИНЦИПІВ
}

\section{T. Holovan}

\section{THE QUESTIONS OF EFFICIENCY \\ OF SOCIAL DIALOGUE IN UKRAINE THROUGH THE LENS OF LEGAL REGULATION OF ITS PRINCIPLES}

\begin{abstract}
Анотація. Метою наукової статті $є$ дослідження питань правового врегулювання принципів соціального діалогу в Україні з точки зору можливості їх ефективної практичної реалізації. Автор акцентує увагу на необхідності належного нормативно-правового врегулювання принципів соціального діалогу в Україні. Адже дотримання та реалізація принципів всіма учасниками соціального діалогу на практиці дозволить досягти означеноївизначеної мети, соціальний діалог стане дієвим інструментом розвитку соціальнотрудових відносин, дозволить запобігти появі та ефективно вирішувати вже наявне широке коло проблем у сфері праці. Автором обгрунтована неефективність реалізації норм Закону України «Про соціальний діалог в Україні» та наявність недостатнього дослідження питань принципів соціального діалогу в Україні. Автор статті дійшов висновку щодо необхідності проведення подальших наукових досліджень у сфері соціального діалогу в Україні, доопрацювання та внесення змін до Закону України «Про соціальний діалог в Україні», що дозволить досягти прогресивних змін у становленні інституту соціального діалогу та досягненні його мети.
\end{abstract}

Ключові слова: соціальний діалог, принципи соціального діалогу в Україні, мета соціального діалогу, держава, громадянське суспільство.

Аннотация. Целью написания научной статьи является исследование вопросов правового регулирования принципов социального диалога в Украине с точки зрения возможности их эффективной практической реализации. Автор акцентирует внимание на необходимости надлежащего нормативно-правового регулирования принципов социального диалога в Украине. Ведь соблюдение и реализация принципов всеми участниками социального диалога на практике позволит достичь указанной цели, социальный диалог станет действенным инструментом развития социально-трудовых отношений, позволит предотвращать появление и эффективно решать уже существующие проблемы в сфере труда. Автором обоснованы неэффективность реализации норм Закона Украины «О социальном диалоге в Украине» и наличие недостаточного исследования принципов социального диа- 
лога в Украине. В статье сделан вывод о необходимости проведения дальнейших научных исследований в сфере социального диалога в Украине, доработки и внесения изменений в Закон Украины «О социальном диалоге в Украине», что позволит достичь прогрессивных изменений в становлении института социального диалога.

Ключевые слова: социальный диалог, принципы социального диалога в Украине, цель социального диалога, государство, гражданское общество.

Abstract. The purpose of writing a scientific article is to study the issues of legal regulation of the principles of social dialogue in Ukraine in terms of the possibility of their effective practical implementation. The author emphasizes the need for proper regulation of the principles of social dialogue in Ukraine and proper research of these issues. After all, achieving effective implementation of the principles of social dialogue to achieve the goal of social dialogue is possible only if they are properly scientifically substantiated, and compliance with the principles of all participants in social dialogue in practice will achieve this goal, social dialogue will be an effective tool for social relations. to prevent the emergence and effective solution of the already existing wide range of problems in the field of labor. The author substantiates the inefficiency of the implementation of the Law of Ukraine "On Social Dialogue in Ukraine" and the lack of research on the principles of social dialogue in Ukraine. The article concludes on the need for further research in the field of social dialogue in Ukraine, the need to refine and amend the Law of Ukraine "On Social Dialogue in Ukraine" in terms of defining the concepts of social dialogue, adjusting the names of some principles and clearly defining the content of each them, which will achieve progressive changes in the formation of the institution of social dialogue and achieve its goal.

Key words: social dialogue, principles of social dialogue in Ukraine, purpose of social dialogue, the state, civil society.

Постановка проблеми. Дієве сучасне забезпечення прав, свобод людини та їхніх гарантій не може існувати без реалізації соціального діалогу. Саме соціальний діалог є засобом досягнення взаємовигідного балансу інтересів працівників та роботодавців, сприяє підвищенню довіри до держави та влади, допомагає досягти соціальної стабільності в державі. Низькі показники ефективності соціальної політики в Україні стали поштовхом до напряму впровадження соціального діалогу. Необхідно зазначити, що 3 розвитком держави, реформуванням влади та визначенням пріоритетів на приведення всіх сфер держави до європейських стандартів коло проблемних питань, які можуть бути вирішені за допомогою соціального діалогу, постійно розширюється. Все це зумовлює своєчасність та важливість проведення наукових досліджень у цій сфері. Відповідно до цього, особливої уваги заслуговують питання принципів соціального діалогу в Україні як основ, на яких побудована та реалізується вся сфера соціального діалогу. Адже наявність прогалин з цих питань перешкоджатиме активному впровадженню соціального діалогу на території України та ефективному досягненню його мети.

Аналіз останніх досліджень. Щодо грунтовного дослідження питань принципів соціального діалогу в Україні можна зазначити, що цей аспект не отримав належної уваги в науці. Правові аспекти соціального діалогу в Україні 
досліджувались такими вченими, як В. В. Жернаков, О. О. Коваленко, М. О. Міщук, С. М. Прилипко, О. А. Трюхан, Г. І. Чанишева, О. М. Ярошенко, В. В. Яцишин. Однак комплексні дослідження принципів соціального діалогу, які є підгрунтям, на якому побудована та реалізується вся сфера соціального діалогу, відсутні.

Формулювання мети статті (постановка завдання). Метою цієї наукової статті є дослідження питань правового регулювання принципів соціального діалогу в Україні, їхньої системи та змісту щодо можливості їхньої ефективної практичної реалізації та уніфікація підходів щодо розуміння правової природи принципів соціального діалогу.

Виклад основного матеріалу дослідження з новим обгрунтуванням отриманих наукових результатів. На сьогодні досить актуальними є дослідження питань становлення та ефективності соціального діалогу в Україні. Відповідно до Конституції України наша держава $\epsilon$ демократичною, соціально та, правовою. Особливий акцент необхідно зробити на тому, що Україна $\epsilon$ соціальною державою. Отже, держава повинна спрямовувати свою політику в напрямі забезпечення прав та законних інтересів членів суспільства. Одним 3 найважливіших напрямів державної політики $\epsilon$ забезпечення розвитку соціально-трудових відносин.

Як зазначає Д. М. Горєлов, «одним з випробуваних інструментів врегулювання соціально-трудових відносин, вирішення широкого кола соціальноекономічних проблем є соціальний діалог - процес визначення та зближення позицій, досягнення спільних домовленостей та прийняття узгоджених рішень сторонами соціального діалогу, які представляють інтереси працівників, роботодавців та органів виконавчої влади й місцевого самоврядування $з$ питань формування реалізації державної соціальної та економічної політики регулювання трудових, соціальних, економічних відносин» $[1$, с.4]. Але, на жаль, «соціальний діалог у країні загалом у його цивілізованій формі знаходиться на початковій стадії розвитку. Головною перепоною на шляху до формування системи дієвого соціального діалогу в Україні $є$ історичні та ідеологічні стереотипи, що дісталися у спадок соціальним партнерам від попереднього режиму» [2, с.236] Перш ніж соціальний діалог досягне своєї мети та стане «основою та передумовою прийняття будь-яких владних рішень на рівні держави щодо будь-яких економічних та соціальних змін в Україні» [3, c.2], необхідно пройти тривалий шлях аналізу наявних помилок, виявлення прогалин, індикаторів та факторів неефективності, визначення шляхів їх усунення, дослідження міжнародного досвіду, опрацювання та наукового обгрунтування всіх елементів соціального діалогу. 3 метою прискорення зазначених процесів виникає необхідність у залученні науковців. Адже реалізація будьяких інституцій, що не мають наукового підгрунтя, приречена на провал.

На сьогодні «практично за всіма найважливішими соціальними показниками світового цивілізаційного розвитку Україна впритул наблизилась до 
небезпечної межі: основні соціальні ризики - бідність, майнова диференціація населення, відчуженість значної кількості громадян від суспільного життя, звуження їх доступу до освіти, медицини і культури - досягли масштабів, які можуть становити реальну загрозу національній безпеці держави. Загалом аналіз ефективності вітчизняної моделі соціального діалогу в Україні свідчить про наявність комплексу проблем, що $є$ актуальними як для суспільства, так i для держави» [4]. В Україні «соціальний діалог на національному, галузевому, територіальному, місцевому і локальному рівнях перебуває на стадії становлення. Сформована за роки незалежності України правова та організаційна база не забезпечує бажаного ефекту соціального діалогу щодо визначення та зближення позицій, досягнення спільних домовленостей та прийняття узгоджених рішень його сторонами, які представляють інтереси працівників, роботодавців та органів виконавчої влади й органів місцевого самоврядування 3 питань формування та реалізації державної соціальної та економічної політики, регулювання трудових, соціальних, економічних відносин» [5, С. 411-413].

Одним 3 основних питань, яке потребує наукового дослідження, $\epsilon$ проблеми правового регулювання принципів соціального діалогу, які зумовлені насамперед своєю значимістю та особливим місцем у цій сфері.

Принципи є тим підгрунтям, на якому побудована та реалізується вся сфера соціального діалогу. Саме принципи допомагають правильно визначити зміст соціального діалогу в Україні. Принаймні так повинно бути. Крім того, принципи зумовлюють зміст майбутніх правових приписів у сфері соціального діалогу.

Термін «принципи» походить від латинського «рrincipium», що перекладається як основа або начало. В. І. Даль визначав термін «принцип» як «наукове чи моральне начало, основу, правило, від якого не відступають» [6, с. 431]. Великий тлумачний словник української мови визначає термін «принцип» як переконання, норма, правило, яким керується хто-небудь в житті або поведінці [7]. Аналізуючи наявні точки зору щодо визначення поняття принципів загалом та принципів соціального діалогу зокрема, можна дійти висновку, що принципи соціального діалогу - це виражені в законодавстві основні засади, керівні положення, які визначають загальну спрямованість соціального діалогу як процесу визначення та зближення позицій, досягнення спільних домовленостей та прийняття узгоджених рішень сторонами соціального діалогу, які представляють інтереси працівників, роботодавців та органів виконавчої влади й органів місцевого самоврядування з питань формування та реалізації державної соціальної та економічної політики, регулювання трудових, соціальних, економічних відносин.

Принципи соціального діалогу закріплені на міжнародному та національному рівнях. На міжнародному рівні принципи соціального діалогу закріплені в Загальній декларації прав людини, прийнятій Генеральною Асамблеєю ООН 10 грудня 1948 року, в Міжнародному пакті про громадянські та політичні 
права від 16 грудня 1966 року, який було ратифіковано Указом Президіi Верховної Ради Української РСР від 19 жовтня 1973 року, в Міжнародному пакті про економічні, сочіальні та культурні права від 16 грудня 1966 року, який було ратифіковано Указом Президії Верховної Ради Української РСР від 19 жовтня 1973 року, в Декларащії Міжнародної організаиіі основних принциипів та прав у світі праиі, ухваленій Міжнародною конферениією пращі на їі 86 сесії в Женеві, що була проведена 18 червня 1998 року, в Конвениіі Міжнародної організаиії праиі про свободу асоиіації та захист права на організаціï № 87 від 09 липня 1948 року, в Конвенції Міжнародної асоціації праці про застосування принципів права на організацію і на ведення колективних переговорів № 98 від 01 липня 1949 року, в Конвенції Міжнародної організації праці про захист прав представників працівників на підприємстві та можливості, що їм надаються № 135 від 23 червня 1971 року, в Конвениіi Міжнародної організаиіï праці про Тристоронні консультації для сприяння застосуванню міжнародних трудових норм від 21 червня 1976 року, в Конвенції Міжнародної організації праці про сприяння колективним переговорам № 154 від 19 червня 1981 року, в Рекомендаціях Міжнародної організації праці щодо колективних договорів № 91 від 29 червня 1951 року, в Рекомендаціях Міжнародної організації праці щодо добровільного примирення та арбітражу № 92 від 29 червня 1951 року, в Рекомендаціях Міжнародної організації праці щодо консультацій та співробітництва між роботодавцями та працівниками на рівні підприємства № 94 від 26 червня 1952 року, в Рекомендаціях Міжнародної організації праці щодо консультацій та співробітництва між державною владою та організаціями підприємців і працівників у галузевому та в національному масштабі № 113 від 20 червня 1960 року та в Хартії Співтовариства про основні соціальні права працівників від 09 грудня 1989 року, в Хартії основних прав Европейского Союзу від 07 грудня 2000 року.

На національному рівні принципи соціального діалогу закріплені в Законі України «Про соціальний діалог в Україні» від 23 грудня 2010 року. Цей Закон не містить визначення поняття принципів соціального діалогу, а лише їх перелік.

Крім того, стаття 3 Закону України «Про соціальний діалог в Україні», яка має назву «Основні принципи соціального діалогу», навіть не визначає зміст задекларованих принципів. 3 цього приводу серед науковців виникає багато дискусій, адже досягнення мети соціального діалогу, яка визначена в преамбулі відповідного Закону, а саме «вироблення та реалізації державної соціальної і економічної політики, регулювання трудових, соціальних, економічних відносин та забезпечення підвищення рівня й якості життя громадян, соціальної стабільності в суспільстві», можливе лише за умови чіткого правового врегулювання зазначеної сфери.

Безумовно, Закон України «Про соціальний діалог в Україні» $є$ суттєвим кроком назустріч впровадженню соціального діалогу, але потребує доопра- 
цювання та внесення відповідних змін щодо питань декларування принципів соціального діалогу.

Зокрема він повинен містити чітке визначення понять, які використовуються в ньому. Це стосується й визначення поняття «принципи соціального діалогу».

Корегування потребує й назва статті 3 зазначеного Закону, адже, як зазначає О. О. Коваленко, «навряд чи слід визнати вдалим такий добір слів законодавця для назви як правової конструкції, так і для назви статті, оскільки в цьому випадку ми маємо справу з тавтологією. Навряд чи в зазначеному випадку - вживанні в конструкції, закріпленій нормативно-правовим актом, можна говорити про фігуру мови, отже, на жаль, маємо констатувати наявність недостатньої культури мови. Застосовуючи слово «принцип», маємо на увазі слово «основний», «основне». Все, що не основне, принципом бути не може. Тому назва ст.3 Закону України «Про соціальний діалог в Україні» та назва правової конструкції, що міститься в ній, потребує виправлення на «Принципи соціального діалогу» [8, С.86].

Також необхідно зазначити, що законодавець, визначаючи принципами соціального діалогу на території України законність та верховенство права, репрезентативність і правоможність сторін та їхніх представників, незалежність та рівноправність сторін, конструктивність та взаємодію, добровільність та прийняття реальних зобов'язань, взаємоповагу та пошук компромісних рішень, обов'язковість розгляду пропозицій сторін, пріоритет узгоджувальних процедур, відкритість та гласність, обов'язковість дотримання досягнутих домовленостей, відповідальність за виконання прийнятих зобов'язань, на жаль, не визначив їхній зміст. Таким чином, на сьогодні потребує розширення стаття 3 Закону України «Про соціальний діалог в України» через внесення відповідних змін, що визначать зміст задекларованих принципів. Це унеможливить їхнє довільне трактування.

Серед науковців також виникають дискусії щодо найменування задекларованих принципів соціального діалогу. Так, Г. І. Чанишева вважає, що, «відповідно до положення актів МОП Ради Свропи, перелік основних принципів соціального діалогу потребує вдосконалення. Потребує уточнення найменування окремих із передбачених в статті 3 Закону основних принципів соціального діалогу».

Науковець пропонує, наприклад, «уточнити найменування принципу репрезентативності й правоможності сторін та їхніх представників та іменувати його принципом повноважності сторін та їхніх представників», мотивуючи свою думку тим, що «представники суб'єктів соціального діалогу повинні мати повноваження брати зобов’язання, що мають юридичну силу i для них самих, і для осіб, яких вони представляють» [9, С.102]

На думку Г. І. Чанишевої, не зовсім відповідає міжнародним актам найменування принципу конструктивності та взаємодії, оскільки «некоректним 
є застосування в найменуванні слова «взаємодія», тому що відносини щодо соціального діалогу вже передбачають взаємодію його сторін. Тому необхідно сформулювати зазначений принцип як принцип довіри і добросовісності у взаємодії сторін та їхніх представників» [9, С.104].

Також суперечливою $\epsilon$ доцільність декларування таких принципів соціального діалогу, як законність та верховенство права, оскільки зазначені принципи визнані загальноправовими. Отже, немає жодної необхідності дублювати в Законі України «Про соціальний діалог в Україні» принципи, закріплені в Конституції України. Хоча й окреме закріплення та подальша реалізація цих принципів є суперечливими, адже в правовій науці висловлюється думка щодо необхідності поєднання зазначених принципів у принцип «правозаконності».

Надалі «практика соціального діалогу має долати межі вирішення суто трудових відносин і конфліктів. У цьому випадку мова йде про перспективи наповнення державної політики ідеологією соціального партнерства та практичну реалізацією положень Закону України «Про соціальний діалог в Україні» [1, с.5].

Отже, практика застосування норм Закону України «Про соціальний діалог в Україні» спонукає до наукового пошуку шляхів вирішення наявних проблем, подолання виявлених суперечностей, прогресивних форм і методів соціального діалогу.

Висновки 3 цього дослідження й перспективи подальших розвідок у цьому напрямі. Загалом належне нормативно-правове врегулювання принципів соціального діалогу в Україні має без перебільшення велике значення. Адже дотримання та реалізація принципів всіма учасниками соціального діалогу на практиці дозволять досягти зазначеної мети, соціальний діалог стане дієвим інструментом розвитку соціально-трудових відносин, дозволить запобігти появі трудових спорів та ефективно вирішувати вже наявне коло проблем у сфері праці.

Досягнення ефективності реалізації зазначених принципів для досягнення мети соціального діалогу можливе лише за умови проведення належного наукового їх обгрунтування. Саме тому актуальність дослідження принципів соціального діалогу не викликає сумнівів.

Особливо слід звернути увагу на якість та обгрунтованість змісту норм Закону України «Про соціальний діалог в Україні», адже він потребує суттєвого доопрацювання. Насамперед необхідно визначити понятійний апарат, що використовується законодавцем в зазначеному Законі. Крім того, потребує аналізу зміст ст. 3 Закону України «Про соціальний діалог в Україні», якою закріплений перелік принципів соціального діалогу. У цьому випадку передусім необхідно визначити їхній перелік, найменування та зміст. 


\section{Література}

1. Формування соціального діалогу в сучасних умовах: світовий досвід та українська практика / Горєлов Д. М., Корнієвський О. А., Опалько Ю. В., Палій Г. О. Київ: НІСД, 2011. 47c.; 2. Петроє О. М. Соціальний діалог у державному управлінні: європейський досвід та українські реалії: монографія. Київ: НАДУ, 2012. 304 с.; 3. Соціальний діалог в Україні в контексті підписання угоди про асоціацію - виклики та пропозиції. Київ, 2014. URL: https://bureau.in.ua/downloads/social-dialogue/Ukraine.pdf.; 4. Давидюк О.О.Соціальна безпека: проблеми теоретичного аналізу та побудови показників. URL: cpsr.org.ua/index.php.option...id; 5. Трощинський В. П., Петроє О.М. Соціальний діалог i соціальне партнерство як засадничі принципи державного управління. Стратегія державної кадрової плітики - основа модернізації країни: матеріали Всеукр. наук.-практ. конф. за міжнар. участю до 15-річчя галузі науки «Державне управління». Київ: НАДУ, 2012. С. $411-$ 413; 6. Даль В. И. Толковый словарь живого великорусского языка / в 4 т. Москва: Гос. издво иностр. и нац. слов, 1955. Т. 3.; 7. Великий тлумачний словник сучасної української мови / [уклад. і голов. ред. В.Т. Бусел]. Київ, Ірпінь: Перун, 2005. 1728 с.; 8. Коваленко О. О. Окремі проблеми здійснення соціального діалогу в Україні через призму характеристики його принципів у світлі входження до $\mathrm{CC}$. Збірник наукових праць Харківського національного університету ім. Г. С. Сковороди «Право». Харків, 2017. Вип.28. С. 85-90; 9. Чанишева Г. І. Основні принципи соціального діалогу у сфері праці. Вісник південного регіонального центру Національної академії правових наук України. 2014. № 1. С. 100106. URL: http://nbuv.gov.ua/UJRN/vprc_2014_1_12; 10. Про соціальний діалог в Україні: Закон України від 23 груд. 2010 р. № 2862-VI. URL: http://zakon4.rada.gov.ua/laws/ show/2862-17; 11. Конституція України: Закон України від 28.06.1996 р. № 254к/96-ВР. URL: http://zakon4.rada.gov.ua/laws/show/254\%D0\%BA/96-\%D0\%B2\%D1\%80; 12. Комітет 3 питань соціальної політики, зайнятості та пенсійного забезпечення провів «круглий стіл» на тему: «Соціальний діалог як інструмент взаємодії громадянського суспільства і держави» Верховна Рада України. URL: http://www.rada.gov.ua/news/Novyny/151210.html. 